\title{
LEARNER-CONTENT INTERACTION IN AN ONLINE ENGLISH LEARNING COURSE AT A VIETNAMESE UNIVERSITY
}

\author{
Pham Ngoc Thach* \\ Vice President, Hanoi University, Km 9, Nguyen Trai, Thanh Xuan, Hanoi, Vietnam
}

Received 27 June 2018

Revised 26 September 2018; Accepted 27 September 2018

\begin{abstract}
Interaction plays a critical role in both traditional and online learning processes. For online learners of English, interaction with the course content is especially vital because it provides them with necessary knowledge in language competence and contributes to the success of online learning. This paper presents the findings of a study about learner-content interaction in an online English language learning course implemented at a university in Vietnam. The study findings reveal that the learners were confident in using the online course, but they did not particularly appreciate its usefulness. The study suggests that in the context where online language learning is at infancy like Vietnam, providing continuous technical support is crucial to promote autonomous learning.
\end{abstract}

Keywords: learner-content, interaction, usefulness, macro skills, automatic speech recognition (ASR), Vietnam

\section{Introduction}

Globally, online learning has become a popular trend thanks to the boom in the application of the Internet in education in general and language learning in particular. Past studies have shown that there are many benefits for learners in online language learning, especially for shy ones who find face-to-face interaction a big challenge (Wu \& Liu, 2012; Wu \& Marek, 2013). Some of those benefits include increased confidence, motivation and ability for learners to communicate with peers, especially with native speakers of the target language they are studying. Among the three types of interaction (learner-learner, learner-instructor and learner-content interactions) (Moore, 1989),

Tel.: 84-913231773

Email: thachpn@hanu.edu.vn the interaction between the learner and course content plays an important role because of its contribution to the success of the learning outcomes and course completion (Tuovinen, 2000; Zimmerman, 2012).

Since the beginning of computer assisted language learning (CALL), attention has been paid to the development of content (e.g. materials and interactive exercises) for online courses to foster learners' macro language skills (listening, speaking, reading and writing) and language areas (e.g. grammar, pronunciation). With the participation of both computer experts and language educators, online language courses have been able to provide learners with various activities or exercise types such as multiple choice, matching, point-and-click and simple form filling. Most of the exercises are designed with task-based instruction, which is useful 
to second language learning (Bolliger \& Wasilik, 2009).

As for listening skills, the use of computer and web technology has been proven to make learners' listening comprehension more effective and efficient in which learners can get instant feedback on their performance (Bui, 2004; Roussel, 2011; Giang, 2004). Regarding reading, empirical studies have claimed that technology enhances learners' comprehension of input, and reading comprehension (Taylor, 2009). In terms of online language writing, the application of advanced technology has made immediate corrective and targeted feedback possible (Dodigovic, 2007) and learners' frequency of editing their own written works increases (Yoon, 2008). In respect of speaking, it has been claimed in the literature that with automatic speech recognition (ASR) technology learners can improve their pronunciation proficiency and speaking skills accordingly (Carey, 2004; Chiu, Liou, \& Yeh, 2007).

One of the critical issues concerning learner-content interaction is the usefulness or quality of the interaction. In developing countries, where online learning at the higher education level is still in its infancy (Satar \& Özdener, 2008), the assessment of quality of course content has not been considered seriously. The implementation of an online course is sometimes based on the decision of the management board with little consultation with instructors or learners and there are concerns about the content of the online course (Chiu et al., 2007). Another important issue is the relationship between quantity and quality of learners' interaction with the content. Some researchers posited that there was a positive correlation between access rates (or time on tasks) and final grades (Chen, Zhang, \& Liu, 2013; Zimmerman, 2012). However, other researchers viewed that it was the quality that mattered, not quantity of interaction, i.e. the amount of interaction time or the scores they get from doing online tasks (Garrison \& Cleveland-Innes, 2005; Lee, 2012). In some instances, higher education institutions made interaction with content compulsory to ensure highest possible frequency of interaction. However, some researchers have suggested that standard for online teaching should not contain arbitrary thresholds for required interaction (Grandzol \& Grandzol, 2010).

One of the purposes of this study is to examine the learners' perceptions about the usefulness of their interaction with the content of an online English course used at a university in Vietnam. The specific research question for this study was:

How useful is the learners' interaction with course content of an online English language course?

The study used Moore's (1989) theory of interaction as a framework to contribute to better understanding of online learner-content interaction in a country where online learning is at infancy; English is a foreign language; the learners are considered passive and technological and online teaching pedagogy are yet as advanced as in the developed countries (Dang, 2010; Le, 2013; Satar \& Özdener, 2008).

Moore's (1989) theory of interaction posited that in distance education in general and online learning in particular there are three types of interaction: learner-content, learner-instructor and learner-learner. It is very important to make a clear distinction among these three types of interaction in order for educators to agree on the concept and to avoid misunderstanding in the use of different media. Of these three types, learner's interaction with content of subject of study is the process that shapes educational 
experiences, resulting in changes in the learner's knowledge, perspective, mindset, etc. In the oldest form of distance or online learning, this type of interaction was mostly one way and learning was largely selfdirected. Nowadays, with the development of advanced information technology, there is more automated interaction whereby learners can 'talk' to the computer and get instant feedback from it.

\section{Method}

\subsection{The participants}

The participants in this study were 210 first year students who used an online English course (described below) as part of their four-year study for a Bachelor of Arts degree specializing in interpreting and translation at a Vietnamese university. In the first two years of this degree, they focused on English language practice, both in traditional (face-to-face) classes and online. In the traditional classes (about 12 hours per week), the participants studied macro language skills with the lecturers, some of whom were also assigned to supervise the learners' online study. At the beginning of the study programme, the learners were given a half-day orientation session on how to use different components of the online course (see below).

\subsection{The course}

The online course in this study was a commercially available language learning platform (https://www.edusoftlearning.com/ learning-solutions/) used at a Vietnamese university. The main content of this course was grouped into three levels of English proficiency: basic, intermediate and advanced; each of which was further divided into sublevels as shown in Figure 1. Depending on the learners' level of English (suggested through the placement test), the instructors assigned the learners with some appropriate levels only, or all available levels. Better students might be assigned with all levels so they could work at their own pace while weaker students were assigned with one suitable level only and moved up as they progressed.

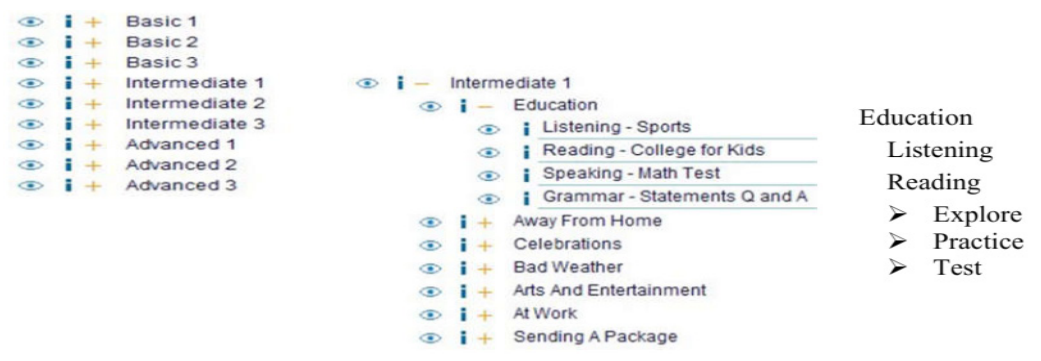

Figure 1. Course content

In each level there were eight units, which covered different topics such as family life, sports, communication and business. For each unit, the learners had a choice of practicing their listening, reading, speaking and grammar. In each of these components, the learners were advised to follow three steps.
First, they should read the 'Explore' section to get some inputs presented in different multimedia formats such as audio, video and text. Next, they had to do the exercises in the 'Practice' section, for example filling in blanks, answering questions and matching. The learners often received instant automated 
feedback from the system about the correctness of their answers. Finally, they could move on to the 'Test' section to consolidate what they had done in the previous steps.

The course included the automatic speech recognition (ASR) technology in the listening and speaking practice entitled Record Yourself. After doing their listening comprehension practice, the learners selected different sentences to listen and repeat. Their repetition was recorded, and scores were given to tell them the accuracy of the oral production, which was sent to the instructors for comments. In the speaking component, the learners could do the same, and/or enhance their verbal reaction by responding to prompts in a dialogue. The majority of speaking practice in this course was mainly in the form of 'listen and repeat'. Figure 2 illustrates an example of the system's response to the learners' oral production.

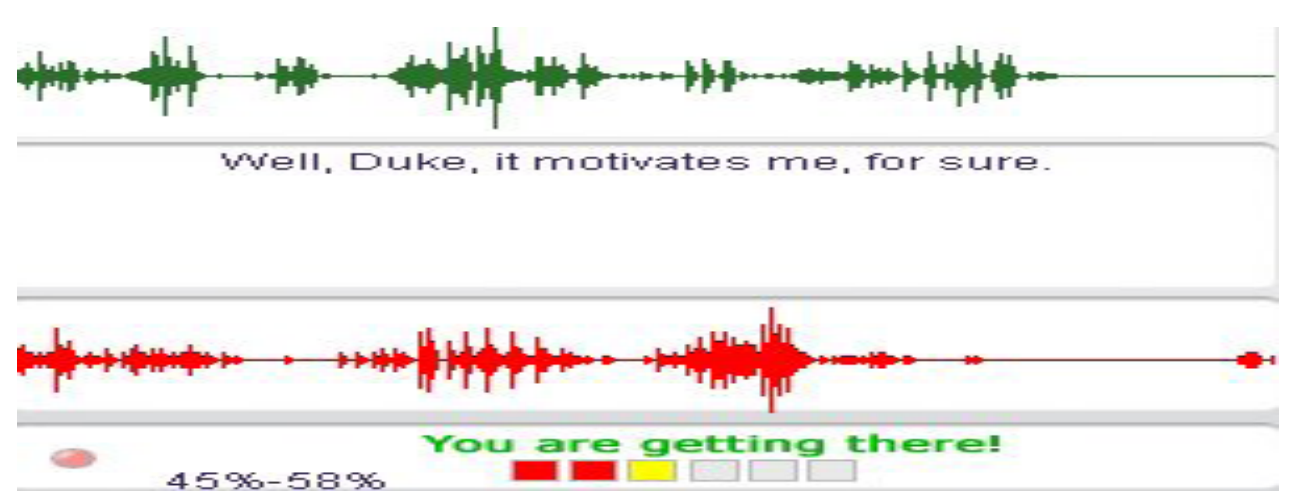

Figure 2. Record yourself tool

In the above example, a learner listened to the sample sentence, "Well, Duke, it motivates me, for sure" as many times as necessary to acquire the pronunciation of individual words as well as the stress and rhythm of the whole sentence. Afterward, s/he recorded the sentence and received the visual display of the score (e.g. $45 \%-58 \%$ ) showing the match between the learner's oral production and the sample one. This repetition and recording could be done as many times as the learner wished in order to increase the score. However, the system could not tell the learner which individual sound(s) that were rightly or wrongly pronounced, nor could it provide instructions on how to improve the performance.

In addition to the above-mentioned content, the online course also had supplementary components to help the learners enhance their vocabulary, idioms and fixed expressions as well as general knowledge through various reading comprehension materials.

The above online course was used in a blended mode at the university. At the beginning of each semester, the instructors, who were also the class lecturers, assigned all the learners with some study levels (e.g. Intermediate $2 \& 3$ ) depending on the learners' level of English. The learners were also required to complete $80 \%$ of interaction with the content of the assigned levels before the end of the semester tests. However, there was little integration between what the learners had to practice in the online course and what was taught in the classroom. The content of the online course was not included in the endof-the-term tests (usually after every four months of study). 


\subsection{Data collection and analysis}

In this study, learners' interaction with the content of the course was retrieved from the teacher management system (TMS) including learners' time on task. In order to obtain the learners' perception, a survey questionnaire was designed and administered to collect information about the following aspects:

(i) level of confidence in using the online course,

(ii) perceived usefulness of interaction with the course content, and

(iii) suggestions to enhance the usefulness of the course content.

The survey questionnaire was based on the Online Learning Readiness Scale (OLRS) with five dimensions: self-directed learning, motivation for learning, computer/Internet self-efficacy, learner control, and online communication self-efficacy (Hung, 2010). Once the questionnaire was developed it was emailed to five instructors who had experience with the online course. This was aimed to obtain their professional comments and to ascertain face validity and content validity for the instrument. Basing on the feedback of the instructors a few items of the questionnaire were revised to make it more focused on the usefulness of the learners' interaction with the course content. In respect of the reliability of the survey items on the usefulness of interaction with the course content, the mean inter-item correlation was 0.2, which was optimal according to Briggs and Cheek's (1986) recommendation.

The quantitative data from the survey were processed using simple descriptive statistics (Cramer, 2003) and statistical analysis such as chi-square test for independence (Pallant, 2011), using the Statistical Package for the Social Sciences (SPSS - version 21). The qualitative data were analysed using content analysis (Miles \& Huberman, 1994; Miles, Huberman, \& Saldaña, 2014). The interpretation of the results was facilitated by using Moore's (1989) conceptual framework of online interaction. The following section of the paper presents the study results.

\section{Results}

\subsection{Confidence in using the online course}

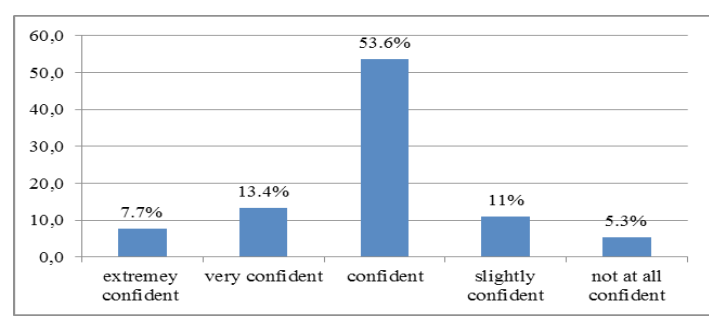

Figure 3. Level of confidence in using the online course

Figure 3 shows that the learners of this course had a relatively high level of confidence in using the course. Over $74.7 \%$ of them reported that they were confident or very confident in using it. This result reveals that the orientation at the start of the online study could provide learners with basic skills on how to use the different components of the online course. However, over a quarter of learners were still not confident in the interaction with content, which suggested that continuous support to the learners during the online study time was crucial to maximise what the course offered.

\subsection{Perceived usefulness of course content}

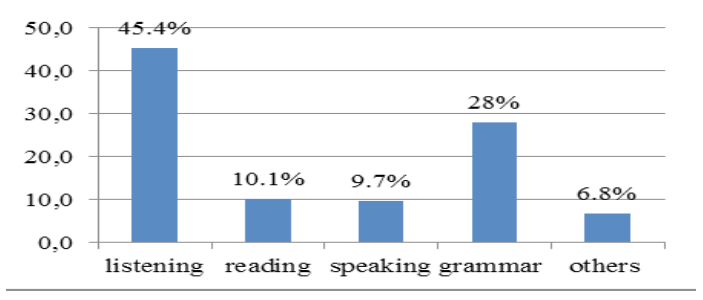

Figure 4. Usefulness of interaction with macro skills and online course 
The data in Figure 4 show that the learners found practice with listening and grammar the most useful activities - $45.4 \%$ and $28 \%$ respectively, followed by doing the reading and speaking practice (about $10 \%$ each). Nearly seven percent of the learners did not share their perceptions about their interaction with the course content.

In order to examine if there is an association between the learners' confidence in using the online course and their overall perception of its usefulness, a chi-square test for independence was performed and the result indicated a significant relationship, $\chi^{2}$ (df 4 , $n=209)=14.8, p=.005$. This seems to show that the more the learners were confident in using the online course, the more they found it useful.

\subsection{Time on tasks}

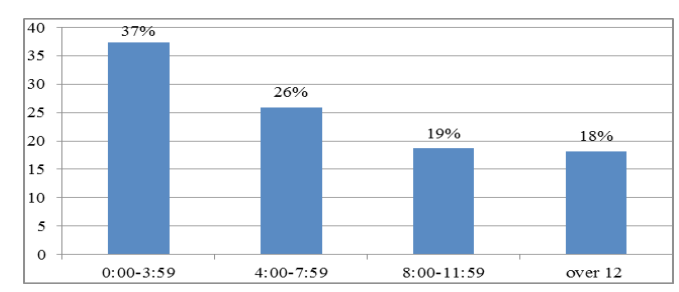

Figure 5. Time on tasks (in hours)

The teacher management system of this online course allowed the researchers to gather information about the learners' total hours invested in the seven months of their online study. Figure 6 showed that the learners who spent less than four hours accounted for almost $40 \%$ of the participants. Those who spent over 12 hours accounted for only $18 \%$. Nevertheless, the above data did not indicate the quality of the learners' interaction with the course content. This was consolidated through the results of chi-square tests, which interestingly showed that there was not a significant association between the learners' time on tasks and perceived usefulness of the course content, $\chi^{2}(d f 6, n=209)=8.3, p=0.22$.

\subsection{Learners' suggestions to enhance the course usefulness}

In the open-ended question of the survey, the participants were invited to express their suggestions to make the course content more useful in the interaction processes. Their opinions were divided into different groups. While some viewed that the content had to be updated and interesting with more [educational] games and attractive design, others stated that the interaction with the course content should not be made compulsory. There were a few suggestions to link the course content with the end-of-semester tests and improve the quality of the internet connection speed as well as making the course compatible with other operating systems instead of the Internet Explorer only. Others wanted more difficult exercises and varied topics in the study units. Followings are some of their comments:

- Change the browser IE into Google Chrome;

- Easier to access by many ways, not only IE; More attractive design; More useful exercises

- EDO should be upgraded the content as well as the quality of connection. If it can develop the interactiveness, maybe I will be more interested in.

- EDO should delete the grammar part; and improve the sound quality in the listening part; The best thing is that EDO should follow the formal of IELTS.

- More interesting topic \& contents; Cheaper; Guided by teacher in each lesson

\section{Discussion}

The findings detailed in the above section present a few interesting points for discussion. 
First of all, in respect of the learners' selfefficacy in using the online course, the study results indicated that the majority of learners were confident in using the course. This result was confirmed through the chi-square tests, which showed significant associations between the learners' confidence in using the course and their perceived usefulness of its content. According to Hung et al (2010) orientation for courses should help the learners encounter as few technical difficulties during their study as possible. This is especially true for a language learning course which is embedded with automatic speech recognition (ASR) technology. Learners need to be efficient in performing such actions as checking the microphone, clicking the record button and hearing their voice again. The failure of any hardware, software (ASR technology) or the performance of the above actions can demotivate learners from oral practice. However, over $16 \%$ of the learners were still not confident in using the course. They might have encountered some of the abovementioned (technical) failure and thus did not find speaking practice particularly useful. Therefore, it is suggested that continuous support from technical staff and instructors be needed throughout the study duration.

Secondly, the learners' highest preference to the practice with the listening skill suggests that this practice was the most useful. During their study at school, little attention was paid by the teachers to this skill, and thus the learners were normally weak at it (Le, 2011; Van,2011). Having a chance to do the listening practice again and again could have helped them improve a lot. This finding supports previous research into this area, which has revealed that learners' listening comprehension is more useful through the use of computer and web technology (Brett, 1997; Lee, 2007; Roussel, 2011). In the current trend of using available online resources such as Youtube, Ted Talk for teaching listening comprehension, it is recommended that pedagogical support (prelistening, key vocabulary) be provided to learners (Hubbard, 2017).

The learners' lack of preference for the reading skills could have been because of the boredom of the reading practice, both in the traditional and online contexts (Le, 2011). In addition, the automated feedback from the system did not provide the learners with explanations why their answers were right or wrong, unlike in the traditional context. Hence, the learners might have been confused about some of the feedback, especially when they could not comprehend why an answer was incorrect. So although past studies have shown some benefits of using technology to enhance learners' reading comprehension (Leffa, 2012; Marzban, 2011; Taylor, 2009), further investigations are needed to examine the role of such affective variables as interest, motivation and real usefulness of doing online reading comprehension tasks (Abraham, 2008; Shawback \& Terhune, 2002).

In respect of speaking practice, the learners of this online course perceived relatively low usefulness of the practice. This was possibly because the speaking practice in the course were mostly 'listen and repeat' in nature. Thus after a certain time of working with it the learners might have become bored and stopped the practice. The result of this study is different from the findings of the study by Chiu at el. (2007) which revealed that the ASR based practice met the learners' expectations of learning English. However, in Chiu's (2007) study, the English major group did not show major improvement after the oral practice. The learners of this study were also English major students, so the simple practice of 'listen and repeat' might not have been useful for them either. 
In this study, the insignificant association between the learners' time on tasks and their perceived usefulness of the course content corroborates the results of earlier studies which have revealed that quantitative method of evaluating online learning is questionable (Chen et al., 2013; Sun et al., 2008). In other words, the simple adding-up of the amount of time spent or number of exercises completed did not truly reflect the quality of the interaction. Past studies have revealed that the quality of interaction was more important than that of quantity (Garrison \& Cleveland-Innes, 2005; Lee, 2012). Hence, the requirement of making the learners complete $80 \%$ of interaction with the assigned study levels before the end of a semester was more of administrative significance than academic one. Indeed, it was suggested by a few researchers that imposing arbitrary thresholds for required interaction might not be an effective measure to encourage online learning (Grandzol \& Grandzol, 2010).

\section{Conclusion}

This paper presents the findings of a study examining the learners' perceived usefulness of the course content of an online English language learning course in Vietnam. Two key conclusions could be drawn from the findings of the study. In terms of macro skills improvement, the learners benefited the most from the practice in listening skills, and the least in speaking skills. Therefore, it is recommended that the design of future online course should be improved to further enhance the learners' oral practice instead of simple 'listen and repeat' or 'listen and respond'. In respect of the quality of interaction, the study indicates that the amount of time invested in doing the online practice did not reflect the quality of interaction. Again, this raises the need to design the online practice to facilitate the learners' meaningful interaction with the course materials. It is the quality of interaction that was more important than the quantity (Lee, 2007).

The practical implications for this study are for both the course managers and to some extent, the instructors. Firstly, the managers should involve the instructors in the development of an online course content as well as the design of the accompanying exercises because they are the ones who provide guidance to the learners during the study processes. They are also responsible evaluating the learners' study outcomes. Hence, the instructors' involvement might be able to create a sense of alignment between online study and overall learning objectives (Koszalka \& Ganesan, 2004). In addition, there is a need to involve technological experts to ensure that the developed content is well embedded in an online learning platform to help the learners make the most of the advantages that advanced technologies can offer.

Secondly, the results of this study show that start-up orientation is very important to familiarize the learners with different parts of an online course. Nevertheless, in order for the learners to become autonomous in their online study, it is necessary to provide the continuous guidance and impose certain rules and structures including personal accountability and positive interdependence in the first few months of the study (Abrami et al., 2011). Past studies have shown that CALL and computer-mediated communication seem to be useful in promoting autonomous learning (Wach, 2012), but the learners' autonomy does not occur voluntarily. Similarly, it has been observed by Eneau and Develotte (2012) that learners need the continuous encouragement of instructors in order to build their autonomy 
both in self-learning and in cooperating with others. This also raises a challenge for the instructors: coping with pedagogical shift from traditional to online teaching (Vi, 2005).

\section{Limitation}

The findings in this study are subject to a number of limitations. Firstly, the study was conducted with only one cohort of learners at a Vietnamese university. This means that the study findings might not be transferable to other groups of learners or institutions. Secondly, the study is limited by the lack of rich qualitative data about the learners' interaction with the content. Future studies need to obtain more qualitative data such as interview and focus group discussion to obtain more indepth information and perceptions from the learners. Alternatively, experimental studies might be needed to gather empirical data about the learners' actual online behaviour both quantitatively and qualitatively including pre- and post- tests to investigate the changes of the learners' English language proficiency over a certain period of online study. Such research will be able to provide more comprehensive findings about the usefulness of learner-content interaction in an online English language learning course.

\section{References}

\section{Vietnamese}

Bùi Thu Giang (2004). Luyện kỹ năng nghe hiểu với sự hỗ trợ của công nghệ thông tin. Một số bài tập ứng dụng: Tap chí Khoa hoc ĐHQGHN: Ngoại ngũu, 20(3), 51-59. https://js.vnu.edu.vn/FS/article/ view/4105

\section{English}

Abraham, L. B. (2008). Computer-mediated glosses in second language reading comprehension and vocabulary learning: A meta-analysis. Computer Assisted Language Learning, 21(3), 199-226.
Abrami, P. C., Bernard, R. M., Bures, E. M., Borokhovski, E., \& Tamim, R. M. (2011). Interaction in distance education and online learning: Using evidence and theory to improve practice. Journal of Computing in Higher Education, 23(2-3), 82-103.

Bolliger, D. U., \& Wasilik, O. (2009). Factors influencing faculty satisfaction with online teaching and learning in higher education. Distance Education, 30(1), 103-116.

Brett, P. (1997). A comparative study of the effects of the use of multimedia on listening comprehension. System, 25(1), 39-53.

Briggs, S. R., \& Cheek, J. M. (1986). The role of factor analysis in the development and evaluation of personality scales. Journal of personality, 54(1), 106-148.

Carey, M. (2004). CALL visual feedback for pronunciation of vowels: Kay Sona-Match. CALICO Journal, 21(3), 571-601.

Chen, L., Zhang, R., \& Liu, C. (2013). Listening strategy use and influential factors in Web-based computer assisted language learning. Journal of Computer Assisted Learning, 30(2013), 207-219.

Chiu, T.-L., Liou, H.-C., \& Yeh, Y. (2007). A study of web-based oral activities enhanced by automatic speech recognition for EFL college learning. Computer Assisted Language Learning, 20(3), 209. 233.

Cramer, D. (2003). Advanced quantitative data analysis. England: McGraw-Hill International.

Dang, T. T. (2010). Learner autonomy in EFL studies in Vietnam: A discussion from sociocultural perspective. English Language Teaching, 3(2), 3-9.

Dodigovic, M. (2007). Artificial intelligence and second language learning: An efficient approach to error remediation. Language Awareness, 16(2), 99-113.

Eneau, J., \& Develotte, C. (2012). Working together online to enhance learner autonomy: Analysis of learners' perceptions of their online learning experience. ReCALL, 24(1), 3-19.

Garrison, D. R., \& Cleveland-Innes, M. (2005). Facilitating cognitive presence in online learning: Interaction is not enough. The American Journal of Distance Education, 19(3), 133-148.

Grandzol, C. J., \& Grandzol, J. R. (2010). Interaction in online courses: More is not always better. Online Journal of Distance Learning Administration, 13(2). Retrieved from http://www.westga. edu/ distance/ojdla/summer132/Grandzol_ Grandzol132.pdf

Hubbard, P. (2017). Technologies for Teaching and Learning L2 Listening. In the Handbook of Technology and Second Language Teaching and Learning ( $1^{\text {st }}$ edition). John Wiley@ Son Inc.

Hung, M.-L., Chou, C., Chen, C.-H., \& Own, Z.-Y. 
(2010). Learner readiness for online learning: Scale development and student perceptions. Computers \& Education, 55(3), 1080-1090.

Koszalka, T., \& Ganesan, R. (2004). Designing online courses: A taxonomy to guide strategic use of features available in course management systems (CMS) in distance education. Distance Education, 25(2), 243-256.

Le, Q.X. (2013). Fostering learner autonomy in language learning in tertiary education: an intervention study of university students in Hochiminh City, Vietnam. (Doctoral thesis, University of Nottingham, UK). Retrieved from http://eprints.nottingham. ac.uk/13405

Le, S. T. (2011). Teaching English in Vietnam: Improving the provision in the private sector. (Doctoral dissertation, Victoria University, Melbourne, Australia). Retrieved from http://library.vu.edu. $\mathrm{au} /$ record $=\mathrm{b} 2237480$

Lee, J. (2012). Patterns of interaction and participation in a large online course: Strategies for fostering sustainable discussion. Educational Technology \& Society, 15(1), 260-272.

Lee, T.-C. (2007). Improving English reading and listening by integrating a web-based CALL system into classroom instruction. Journal of Instruction Delivery Systems, 21(3), 21-29.

Leffa, V. J. (2012). Using an electronic dictionary to understand foreign language texts. Trabalhos em Lingüística Aplicada, 21, 19-29.

Marzban, A. (2011). Improvement of reading comprehension through computer-assisted language learning in Iranian intermediate EFL students. Procedia Computer Science, 3(2011), 3-10.

Miles, M. B., \& Huberman, A. M. (1994). Qualitative data analysis: An expanded sourcebook. Thousand Oaks, CA: SAGE.

Miles, M. B., Huberman, A. M., \& Saldaña, J. (2014). Qualitative data analysis: A methods sourcebook. Thousand Oaks, CA: SAGE.

Moore, M. G. (1989). Editorial: Three types of interaction. The American Journal of Distance Education, 3(2), 1-7.

Pallant, J. (2011). SPSS survival manual: A step by step guide to data analysis using SPSS. Crows Nest, NSW: Allen \& Unwin.

Roussel, S. (2011). A computer assisted method to track listening strategies in second language learning. ReCALL, 23(2), 98-116.

Satar, H., \& Özdener, N. (2008). The effects of synchronous $\mathrm{CMC}$ on speaking proficiency and anxiety: Text versus voice chat. The Modern Language Journal, 92(4), 595-613.

Shawback, M. J., \& Terhune, N. (2002). Online interactive courseware: Using movies to promote cultural understanding in a CALL environment. ReCALL, 14(1), 85-95.

Sun, P.-C., Tsai, R. J., Finger, G., Chen, Y.-Y., \& Yeh, D. (2008). What drives a successful e-Learning? An empirical investigation of the critical factors influencing learner satisfaction. Computers \& Education, 50(4), 1183-1202.

Taylor, A. M. (2009). CALL-based versus paperbased glosses: Is there a difference in reading comprehension? CALICO Journal, 27(1), 147-160.

Tuovinen, J. E. (2000). Multimedia distance education interactions. Educational Media International, 37(1), 16-24.

Van Van, H. (2011). The current situation and issues of the teaching of English in Vietnam. Japan Institutional Repositories Online, 22(1), 7-18. Retrieved from http://r-cube.ritsumei.ac.jp/ bitstream/10367/4129/1/LCS_22_1pp7-18_ HOANG.pdf

Vi, Vu Tuong (2005). Advantages and Disadvantages of using Computer Network Technology in Language Teaching. VNU Journal of Science: Foreign Languages, 21(2), 61-65. Retrieved from https:// js.vnu.edu.vn/FS/article/view/2103

Wach, A. (2012). Computer-mediated communication as an autonomy-enhancement tool for advanced learners of English. Studies in Second Language Learning and Teaching, 2(3), 367-389. Retrieved from www.ceeol.com

Wu, P.H. N., \& Liu, S.M. (2012). A Social and cultural analysis of computer-mediated communication dialogue in Asian context. Paper presented at the 20th International Conference on Computers in Education, Singapore. Retrieved from http:// www.1sl.nie.edu.sg/icce2012/wp-content/ uploads/2012/12/C6-s-28.pdf

Wu, P.H. N., \& Marek, M. W. (2013). Helping second language literature learners overcome e-learning difficulties: Let-Net team teaching with online peer interaction. Journal of Education and Learning, 2(4), 87-101.

Yoon, H. (2008). More than a linguistic reference: The influence of corpus technology on L2 academic writing. Language Learning \& Technology, 12(2), $31-48$

Zimmerman, T. D. (2012). Exploring learner to content interaction as a success factor in online courses. International Review of Research in Open \& Distance Learning, 13(4), 152-165. 


\title{
TƯƠNG TÁC NGƯỜI HỌC - NỘI DUNG TRONG CHƯO'NG TRİNH HỌC TIẾNG ANH TRỰC TUYẾN TẠI MỘT TRƯỜNG ĐẠI HỌC Ở VIỆT NAM
}

\author{
Phạm Ngọc Thạch \\ Trường Đại học Hà Nội, Km 9, Nguyễn Trãi, Thanh Xuân, Hà Nội, Việt Nam
}

Tóm tắt: Tương tác đóng một vai trò quan trọng trong cả lớp học truyền thống và trực tuyến. Đối với người học tiếng Anh, tương tác với nội dung rất quan trọng vì nó cung cấp cho họ kiến thức về ngôn ngữ và góp phần vào sự thành công của quá trình học trực tuyến. Bài viết này trình bày kết quả nghiên cứu tương tác giữa người học và nội dung của một chương trình học tiếng Anh trực tuyến đã được thực hiện ở một trường đại học ở Việt Nam. Kết quả nghiên cứu cho thấy người học tự tin trong việc sử dụng khóa học trực tuyến này, nhưng họ không đánh giá cao hiệu quả của việc tương tác với nội dung của khóa học. Bài báo khuyến nghị là trong bối cảnh học ngoại ngữ trực tuyến còn đang ở giai đoạn sơ khai như tại Việt Nam, cần liên tục hỗ trợ kỹ thuật cho người học mới có thể giúp họ tự lực trong việc học trực tuyến.

Tù khóa: người học - nội dung, tương tác, hữu dụng, kỹ năng tiếng, nhận dạng giọng nói tự động (ASR), Việt Nam

\section{SURVEY QUESTIONNAIRE}

Dear participants,

My name is Pham Ngoc Thach from Hanoi University. I am doing a study on learners' interaction with content of the online course you used last year, the English Discoveries Online (EDO). Please respond to all the questions by ticking one of the boxes or write in the space provided. The survey will take about 10 minutes to complete. Thank you very much for your time.

1. What's your username for accessing EDO?

2. By the end of last academic year (May 2013), how long had you used EDO?

3. How confident are you in using EDO? Please tick one of the boxes.

\begin{tabular}{|l|l|l|l|l|}
\hline Extremely confident & Very confident & Confident & Slightly confident & Not at all confident \\
\hline & & & & \\
\hline
\end{tabular}

4. Which macro skills in EDO are you most satisfied with? Please tick one of the boxes.

\begin{tabular}{|c|c|c|c|c|}
\hline Listening & Reading & Speaking & Grammar & Others (please specify) \\
\hline & & & & \\
\hline
\end{tabular}

5. What is your overall satisfaction with EDO? Please tick one of the boxes.

\begin{tabular}{|l|l|l|l|l|}
\hline Extremely satisfied & Very satisfied & Satisfied & Slightly satisfied & Not at all satisfied \\
\hline
\end{tabular}




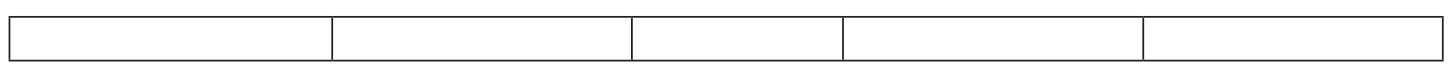

6. In your opinion, which macro skills in EDO is the most useful? Please tick one of the boxes.

\begin{tabular}{|c|c|c|c|c|}
\hline Listening & Reading & Speaking & Grammar & Others (please specify) \\
\hline & & & & \\
\hline
\end{tabular}

7. What's your overall assessment of the usefulness of interaction with EDO? Please tick one of the boxes.

\begin{tabular}{|l|l|l|l|l|}
\hline Extremely useful & Very useful & Useful & Slightly useful & Not at all useful \\
\hline & & & & \\
\hline
\end{tabular}

8. Approximately how much was the interaction with the content of EDO contributed to the results of your semester two test last year? Please tick one of the boxes.

\begin{tabular}{|c|c|c|c|}
\hline Less than $10 \%$ & $10 \%-20 \%$ & More than $20 \%$ & Other percentage \\
\hline & & & \\
\hline
\end{tabular}

9. What could be done to make interaction with the content of EDO more useful?

10. What could be done to make you more motivated to use EDO? 